"Volume 12, No. 1, Juni 2018"

\title{
KONSEPSI KEPEMIMPINAN PENDIDIKAN
}

\author{
Oleh : \\ Kustutik \\ Universitas Ibrahimy Situbondo \\ kustutik2018unib@gmail.com
}

\begin{abstract}
In perspective educational, dominant factor of educational is the concept of development. In the components engaged in educational development are identified by the presence of an intense educational organization overseeing and evaluating course of educational process as well as change the value of education from time to time. As well as less conducive competition between organizations and the loss of the original character of institutions due to social and technological developments. Moreover, it will affect the changes to induvidualism and disintegration problems. Therefore, a proper way or management is needed to "play" in educational development process. As well as manager of an education, the leader or leader must be able to keep moving to adjust development of time.
\end{abstract}

Key Words: Managemen Pendidikan, Pemimpin, Pendidikan

\section{A. Pendahuluan}

Pembangunan pendidikan merupakan salah satu kunci keberhasilan pembangunan. Pimpinan satuan pendidikan sebagai salah satu ujung tombak dalam penyelenggaran pembangunan pendidikan memiliki posisi yang sangat strategis. Ia dituntut untuk lebih mencurahkan perhatian pada organisasiyang dipimpinnya dalam rangka mencapai tujuan secara efektif dan efesien. Tuntutan seperti itu akan semakin menguat sejalan dengan berbagai perubahan secara global yang semakin kompleks dan penuh dengan tantangan. Pelaksanaan pembangunan pendidikan, termasuk pada tingkat satuan pendidikan di indonesia memang tidak mudah. Banyak faktor yang ikut menentukannya, antara lain satuan pendidikan sebagai organisasi didukung oleh komponen sumber daya yang heterogen, anggotanya memiliki latar belakang kepentingan dan bidang tugas yang cukup bervariasi. Lingkungannya sangat luas, dan di warnai oleh berbagai persaingan yang semakin kurang wajar. Individualisme dan kadang disintegrasi. Selain itu pesatnya ilmu 
pengetahuan dan teknologi juga memiliki dampak para perubahan sosial dan pertumbuhan yang tak sama dengan kebudayaan.

Teori manajemen pendidikan yang ilmiah memfokuskan kajiannya pada pentingnya keberadaan pemimpin atau manajer dan perannya dalam suatu lembaga pendidikan yang disebut dengan supervisor. Teori klasik menjelaskan pemanfaatan dan pengangkatan personal pendidikan, tentang tanggung jawab para pelaku pendidikan, serta penciptaan iklim lembaga pendidikan yang ilmiah, penciptaan iklim yang kondusif bagi lembaga pendidikan sangat bergantung pada sumber daya manusianya lemah, meskipun memiliki modal dan fasilitas yang memadai, tidak akan bisa meraih keberhasilan.

Lembaga pendidikan yang memiliki sumber daya manusia yang berkualitas membutuhkan pembagian kerja yang proporsional dan penempatan para kerja menurut kompetensinya masing-masing. Dengan demikian, setiap pelaku pendidikan memikul tanggung jawab penuh sesuai dengan kecakapannya dan mengikuti sistem kerja yang profesional untuk tujuan pendidikan. (Prof. Dr. Akdon, M. Pd.)

Oleh karenanya, pembahasan tentang kepemimpinan telah menunjuk pada suatu fenomena kemampuan seseorang dalam menggerakkan, membimbing dan mengarahkan orang lain dalam suatu kerja sama. Apabila dipadukan dengan istilah pendidikan, muncullah istilah kepemimpinan pendidikan. Pendidikan sendiri menurut Langeveld adalah membimbing anak didik dari tingkat belum deawas menuju kedewasaan. Berarti kriteria keberhasilan pendidikan adalah kedewasaan.

\section{B. Pengertian Kepemimpinan}

Pemimpin dalam bahasa inggrisnya leader adalah orang yang membawahi para pekerja dalam suatu organisasi. Pemimpin memiliki orang-orang yang dipimpin. Pemimpin diartikan pula sebagai orang yang mempunyai wewenang dalam pengambilan keputusan suatu organisasi. Pemimpin juga dapat diartikian sebagai orang yang memeliki kemampuan mempengaruhi orang lain untuk melaksanakan tugas-tugas tertentu yang menjadi harapan dan tujuan sang pemimpin.

Pemimpin adalah subyek atau pelaku dari unsur-unsur yang terdapat dalam kepemimpinan, yaitu adanya kekuasaan, pengaruh, kekuatan, dan pemegang tanggung jawab utama bagi seluruh kegiatan yang dilakuakan oelh bawahannya. Meskipun tidak semua pemimpin

188 JURNAL LISAN AL-HAL 
memiliki jiwa kepemimpinan yang sama, secara timbal balik dan fungsional, kedua konsep tersebut tidak dapat dipisahlkan. ${ }^{1}$

Dari pengertian di atas, terdapat unsur-unsur penting dari makna pemimpin, yaitu sebagai berikut: 1) Unsur kekuasaan, yaitu menguasai organisasi dan mengendalikan struktur organisasi; 2) Unsur instruksional, yaitu berwenang memberikan perintah, tugas, dan segala hal yang harus dilaksanakan oleh bawahannya; 3) Unsur responsibility, yang bertanggung jawab penuh terhadap seluruh kegiatan kinerga organisasi; 4) Unsur pendelegasian, yaitu memiliki hak dan wewenang memindahkan tugasnya kepada bawahanya; 5) Unsur supervis, yaitu yang berkewajiban membina dan mengarahkan anak buahnya; 6) Unsur strategi, yaitu sebagai konseptor yang menyiasati berbagai upaya mengembangkan organisasi; 7) Unsur budaya, yaitu yang membentuk model dan pola perilaku dalam berorganisasi; dan 8) Unsur kharismatika, yaitu yang memiliki kewibawaan yang sifatnya dibentuk secara formal struktural maupun secara kultural.

Delapan unsur yang dimiliki pemimpin menggambarkan kedudukan pemimpin dalam organisasi, baik organisasi dalam arti yang luas maupun yang sempit. Pemimpin adalah orang yang memiliki kedudukan utama dalam menjalankan roda organisasi. Misalnya, suami adalah pemimpin dalam keluarga, maka suami adalah imam bagi istri dan anak-anaknya. Dengan demikian, seorang suami dituntut memiliki kapabilitas untuk mengelola rumah tangganya, baik pengelolaan aspek jasmaniah maupun rohaniahnya. ${ }^{2}$

Semua manusia adalah pemimpin, mimimal pemimpin bagi dirinya sendiri, karena dalam diri manusia terdapat akal dan hati. Akal perlu dipimpin dengan baik sehingga fungsi pikirnya berkembang kearah yang positif dan maslahat. Hati perlu dipimpin agar tidak menimbulkan gejolak nafsu yang membahayakan diri sendiri. Akal dan hati dipimpin ke jalan yang lurus dengan acuan sistem nilai yang berlaku dan ilmu pengetahuan. Rasullah SAW pun perna bersabda bahwa kita semua adalah pemimpin dan akan diminta pertanggungan jawab dari semua perjalanan kepemimpinan kita 3 .

Pemimpin dan kepemimpinan merupakan seni dan keterampilan seseorang dalam memanfaatkan kekuasaannya untuk memengaruhi orang

1 Miftah Thoha, Kepemimpinan dalam manajemen : suatu pendekatan perilaku, (Jakarta: PT. Raja Grapindo Persada, 1995), hlm. 3.

${ }^{2}$ Hikmat. Manajemen Pendidikan, (Bandung: Pustaka Setia, 2009), hlm. 248.

${ }^{3}$ Hikmat. Manajemen Pendidikan, (Bandung: Pustaka Setia, 2009), hlm. 117. 
lain agar melaksanakan aktivitas tertentu yang diarahkan pada tujuan yang ditetapkan. Memimpin adalah mengerjakan niat demi tujuan tertentu, tetapi yang melaksanakan orang lain. Orang yang dipimpin adalah yang diperintah, dipengaruhi, dan diatur oleh ketentuan yang berlaku secara formal maupun norformal. Dengan demikian, pemimpin adalah motivator, stabilisator, kreator, dan dinamisator organisasi.

\section{Arti Kepemimpinan}

Proses pelaksanaan tugas dan kewajiban pemimpin disebut dengan kepemimpinan. Kepemimpinan merupakan sifat dari pemimpin dalam memikul tanggung jawabnya secara moral dan legal formal atas seluruh pelaksanaan wewenangnya yang telah didelegasikan kepada orang-orang yang dipimpinnya. Dalam lembaga pendidikan, misalnya, sekolah dipimpin oleh kepala sekolah yang mendelegasikan kepemimpinannya kepada wakil kepala sekolah atau pejabat lainnya yang berada di bawahnya menurut tugas dan fungsinya masing-masing, misalnya kepada pembantu rektor 1 untuk menjalankan tugas-tugas akademik. Demikian juga, dengan dekan di tingkat fakultas adalah pemimpin yang memiliki bawahan yang trugas kepemimpinannya dibantu oleh para pembantu dekan.

Kepeminminan dapat diartikan sebagai sifat-sifat yang dimiliki seorang pemimpin. Pemimpin yang otoriter artinya orang yang menjalankan kepemimpinan yang kurang demokratis dalam mengambil keputusan. Kekuasaannya bersifat absolut karena seluruh roda kekuasaan dikendalikan oleh dirinya sendiri. Jadi, sifat-sifat seorang pemimpin berarti pula sebagai bentuk dari kepemimpinan.

Kepemimpinan adalah bentuk-bentuk konkret dari jiwa pemimpin. Salah satu dari bentuk konkret itu adalah sifat terampil dan berwibawa serta cerdas dalam memengaruhi orang lain untuk melaksanakan tugastugas yang merupakan cita-cita dan tujuan yang ingin diraih oleh pemimpin. Oleh karena itu, sifat dasar yang biasanya dimiliki pemimpin adalah sebagai berikut: 1) Memiliki pengalaman yang lebih banyak dibandingkan dengan anak buahnya; 2) Memiliki ilmu pengetahuan yang lebih luas dari yang dipimpinnya; 3) Prestasi kerjanya cemerlang; 4) Karir dan jabatannya terbaik dibandingkan yang lain dalam organisasinya; 5) Kesempatan yang lebih besar dalam menempati jabatan tertinggi dan tertentu; 6) Kewibawaan yang dibanggakan oleh anggota organisasi; 7) Meraih kekuasaan secara politik dengan berbagai cara dan strategi; 8) Memiliki para pendukung yang loyal dan komitmen pada visi dan misa yang diembannya; dan 9) Menguasai metode dan teknik dalam mengelola organisasi.

$190 \mid$ JURNAL LISAN AL-HAL 
Dalam organisasi, fungsi-fungsi kepemimpinan bermuara pada lima bentuk utama, yaitu:

1. Manajer, direktur, ketua, presiden, kepala, dan istilah lainnya yaitu pengelolah dan penyelenggara organisasi yang berkaitan dengan fungsi-fungsi manajemen.

2. Pengawas, yaitu yang mengontrol seluruh pelaksanaan tugas dan kewajiban bawahannya.

3. Pembina, yaitu yang memberikan pengarahan dan memberikan contoh dalam melaksanakan tugas organisasi.

4. Pengambil keputusan, yang menetapkan alternatif pemecahan masalah yang dihadapi oleh organisasi yang dipimpinnya, dan

5. Penanggung jawab untuk semua pelaksanaan program organisasi.

Kepemimpinan merupakan pelaksanaan dari keterampilan mengelola orang lain sebagai bawahannya. Mengelolah sumber daya manusia dan sumber daya organisasi secara umum. Oleh karena itu, setiap pemimpin harus memiliki managerial skill yang sangat berpengaruh pada kekuasaan yang dimiliki. Keahlian utama dari kepemimpinan adalah terampil mengendalikan situasi dan kondisi organisasi, yaitu dengan menentukan konsep masa depan organisasi dalam bentuk kerangka kerja yang visioner.

Pendelegasian tugas dan kewajiban yang diserahkan kepada anak buahnya merupakan bagian dari kepemimpinan manusiawi, yaitu menjalin hubungan langsung dengan anak bauhnya dan mengetahui mentalitas dan kinerjanya, sehingga pemimpin adalah penggerak utama anggota organisasi agar dapat bekerja sama dalam mencapai tujuan.

Kerja sama yang dibangun oleh sifat-sifat kepemimpinan didasarkan pada wewenangnya yang diatur oleh norma-norma yang berlaku dalam organisasi. Pengaruh kepemimpinan akan menggerakkan seluruh anak buahnya bekerja secara interelatif dan sinergis, sehingga tujuan organisasi dapat dicapai dengan cara yang efektif dan efisien.

Dalam pancasila sila keempat dikatakan bahwa" kerakyatan yang dipimpin oleh hikmah kebijaksanaan dalam permusyawaratan perwakilan". Dari sila tersebut, secara filosofis, dapat diambil suatu konsep kepemimpinan yang indonesiawi, yaitu sebagai berikut.

1. Kepemimpinan yang dibangun oleh kecerdasan filosofis para pemimpin. Kecerdasan filosofis adalah pandai menemukan hikmah dari setiap penyelenggaraan organisasi, terlebih lagi suatu negara.

2. Kepemimpinan yang menetapkan pengambilan keputusan dengan nilainilai kebijaksanaan, artinya memberikan kemaslahatan bagi seluruh 
kepentingan bangsa dan negara, kebijaksanaan yang memaslahatkan anggota suatu organisasi yang dipimpinnya.

3. Kepemimpinan yang berprinsip pada nilai-nilai demokrasi, yaitu dengan melaksanakan musyawarah dalam pengambilan keputusan dan tidak menganut kepemimpinan otoriter.

4. Kepemimpinan yang pandai memiliki wakil-wakilnya untuk diberi wewenang, tugas, dan kewajiban dalam menjalankan roda organisasi

Dengan konsep kepemimpinan tersebut, arti kepemimpinan dapat dikemukakan sebagai berikut:

1. Prajudi Atmosudirdjo dalam ngalim Purwanto mengatakan bahwa kepemimpinan adalah kepribadian (personality) seseorang yang mendatangkan keinginan pada kelompok orang untuk mencontoh atau mengikutinya, atau yang memancarkan suatu pengaruh tertentu, suatu kekuatan atau wibawa, yang demikian rupa sehingga membuat sekelompok orang bersedia untuk melakukan apa yang dikehendaki.

2. Kepemimpinan dapat pula dipandang sebagai penyebab dari berbagai kegiatan, proses atau kesediaan untuk mengubah pandangan atau sikap (mental/fisik) dari kelompok orang, baik dalam hubungan organisasi formal maupun informal.

3. Kepemimpinan adalah suatu seni, kesanggupan (abality) atau teknik untuk membuat sekelompok bawahan dalam organisasi formal atau para pengikut atau simpatisan dalam organisasi informal mengikuti atau mentaati segala apa yang dikehendakinya, membuat mereka begitu antusias atau bersemangat untuk mengikutinya, bahkan mungkin rela berkorban untuknya.

4. Kepemimpinan dapat pula dipandang sebagai suatu bentuk persuai suatu seni pembinaan kelompok orang tertentu, biasanya melalui humam relations dan motivasi yang tepat, sehingga tanpa adanya rasa takut, orang-orang tersebut bersedia untuk bekerja sama dan membanting tulang untuk memahami dan mencapai segala apa yang menjadi tujuan-tujuan organisasi.

Kepemimpinan dapat pula dipandang sebagai suatu sarana, suatu instrumen atau alat, untuk membuat sekelompok orang bersedia bekerja sama dan berdaya upaya menaati segala peraturan untuk mencapai tujuan-tujuan yang lebih ditentukan. Dalam hal ini, kepemimpinan dipandang sebagai dinamika suatu organisasi yang membuat orang-orang bergerak, bergiat, berdaya upaya secara "kesatuan organisasi" untuk mencapai tujuan-tujuan organisasi.

Berdasarkan pandangan di atas, dapat disimpulkan bahwa kepemimpinan adalah sekumpulan dari serangkaian kemampuan dan sifat

192 JURNAL LISAN AL-HAL 
kepribadian, termasuk di dalamnya kewibawaan, untuk dijadikan sebagai sarana dalam rangka menyakinkan yang dipimpinnya agar mereka bersedia dan dapat melaksanakan tugas-tugas yang dibebankan kepadanya dengan rela, penuh bersemangat, gembira, serta merasa tidak terpaksa ${ }^{4}$.

\section{Fungsi Utama Kepemimpinan}

Fungsi utama pemimpin adalah menjalankan kepemimpinannya dengan baik dan benar, artinya berdasarkan aturan main yang telah di sepakati dan ditetapkan oleh organisasi. Fungsi-fungsi utama yang dimaksudkan adalah sebagai berikut:

1. pengelolah organisasi atau pengendali utama manajemen berorganisasi. Pemimpin yang menjalankan fungsi utama adalah konseptor utama yang merumuskan visi dan misi serta tujuan organisasi, sehingga mulai perencanaan hingga pertanggung jawaban diarahkan pada tujuan yang telah ditetapkan.

2. Motivator, yaitu orang yang mendorong dan memberikan dukungan penuh kepada bawahannya untuk bekerja dengan optimal.

3. Pembuat keputusan yang akan memengaruhi perkembangan dan kemajuan organisasi serta kesejahteraan para anggotanya.

4. Penilai kinerja karyawannya yang akan memberikan penghargaan bagi seluruh prestasi kerja bawahannya.

5. Dinamisator dan katalisator organisasi, yaitu orang yang memajukan organisasi dan mengendalikan situasi dan kondisi yang akan berpengaruh terhadap kemajuan atau kemunduran organisasi.

6. Stabilisator, yaitu orang yang mempunyai kapabilitas terkuat dalam mempertahankan eksistensi organisasi.

7. Supervisior, yaitu yang membina, melatih, mendidik, mengawasi, menilai, dan memberikan contoh kerja terbaik bagi seluruh anggota organisasi yang dipimpinnya ${ }^{5}$.

\section{E. Gaya dan Sifat Kepemimpinan}

Dalam kepemimpinan terdapat beberapa ciri fungsional yang melekat pada seorang pemimpin, yaitu: Watak dan kewibawaan seorang pemimpin, Kekuasaan dalam pekerjaan yang dilaksanakan oleh bawahannya, Hierarki kekuasaan struktural, Ketegasan pengambilan

${ }^{4}$ Hikmat. Manajemen Pendidikan, (Bandung: Pustaka Setia, 2009), hlm. 208.

${ }^{5}$ Ike Kusdyah Rachmawati. Manajemen konsep-konsep Dasar dan Pengantar Teori. (Malang: UMM Press. 2003) hlm. 123-124. 
keputusan, Kecerdasan menganalisis persoalan yang menyangkut kepentingan umum.

Sedangkan untuk sifat-sifat pemimpin yang utama adalah sebagai berikut: 1) Energik, artinya memiliki semangat yang tinggi dan terbaik dibandingkan dengan bawahannya; 2) Emosinya stabil, yaitu telaten dalam melaksanakan tugas-tugasnya; 3) Mampu membangun relasi dengan seluruh bawahannya dan dengan lingkungan eksternal organisasi; 4) Memiliki motivasi yang kuat di dalam jiwanya untuk memimpin dengan baik; 5) Idealis, artinya memiliki gagasan dan cita-cita yang sangat tinggi untuk dirinya dan organisasinya; 6) Ahli dalam membimbing dan mengarahkan anak buahnya; 7) Terampil mengendalikan organisasi dan menjalin kerja sama dengan anak buahnya dan dengan organisasi eksternal; 8) Ahli membentuk budaya organisasi dan menjalin hubungan sosial; 9) Rasional dalam memevahkan masalah; 10) Memiliki moralitas yang patut diteladani oleh anak buahnya; 11) Inonatif, kreatif, dan konstruktif; 12) Konseptor yang handal; 13) Berwawasan luas dan mengedepan; 14) Sehat jasmani dan rohani; 15) Memiliki keahlian teknis; 16) Jujur dan amanah; 17) Berpengalaman; 18) Penuh rasa tanggung jawab; 19) Demokratis; 20) Memahami keadaan dan kemauan anak buahnya dan 21) Ahli berkomunikasi.

Seorang pemimpin harus memiliki keahlian manajerial dan memahami hal-hal yang sifatnya teknis agar memudahkan ia mengarahkan dan membina anak buahnya. Ia harus memiliki keterampilan berkomunikasi dengan orang lain, memiliki kepiawian berinteraksi, membangun relasi, dan bersosialisasi, sehingga kepemimpinannya berjalan efektif. Ia juga harus memiliki human relation skill, keahlian berhubungan dengan orang lain, yaitu pandai membuat relasi baru dan berinteraksi dengan seluruh anak buahnya dan dengan lingkungan sekitarnya.

Gaya kepemimpinan itu berbeda-beda. Menurut Hadari Nawawi, ada 4 gaya kepemimpinan, yaitu6: Gaya kepemimpinan otokratis, Gaya kepemimpinan militeristis, Gaya kepemimpinan paternalistis, dan Gaya kepemimpinan demokratis.

1. Kepemimpinan yang Otokratis. Dalam kepemimpinan yang otokratis, pemimpin bertindak sebagai diktator terhadap angota-anggota kelompoknya. Pemimpin otokratis adalah pemimpin yang memiliki wewenang (authority) tunggal. Pemimpin otokratis dapat disebut

6 Hadari Nawawi. Kepemimpinan Menurut Islam. (Yogyakarta: Gadjah Mada University Press, 2001), hlm. 169.

194 JURNAL LISAN AL-HAL 
sebagai pemimpin yang tidak demokratis. Ciri-ciri pemimpin yang bergaya otokratis adalah: a) Menjadikan organisasi sebagai milik pribadi; b) Menetapkan tujuan pribadi dengan tujuan organisasi; c) Memandang bawahan sebagai alat yang tidak berdaya; d) Tidak mau menerima kritik, saran, dan pendapat; e) Bergantug pada kekuasaan formal yang dimiliki; f) Memimpin dengan cara paksa. Gaya otokrasi dimiliki sepenuhnya oleh pemimpin yang diktatoristik dan absolut, yang merendahkan arti musyawarah dan menolak pertisipasi anak buahnya dalam pengambilan keputusan.

2. Tipe Militeristik. Seorang pemimpin yang bertipe militeristis ialah seorang pemimpin yang memiliki sifat-sifat berikut: Instruksional, Pangkat dan jabatan menjadi alat utama memaksa anak buahnya untuk melaksanakan tugas, Serba formalistik, Disiplin yang kuku, Tertutup bagi kritik, Formal seremonial yang pelaksanaan tugas

3. Gaya Paternlistik. Gaya paternalistik ialah: Menyempelekan kemampuan anak buah, Over protective, terlalu memanjakan anak buah dan terlalu melindungi, Tertutup bagi pengembangan kaderisasi, Kreativitas anak buah tertekan oleh sikap god father-nya, Mahatahu, jadi anakbuah belum banyak tahu, Close management bagi anak buahnya dan All handle untuk seluruh rencana kerja.

4. Gaya atau Model Kontingensi Fielder. Gaya kepemimpinan ini dikembangkan oleh Fred E. Fielder. Menurut gaya ini, ada tiga variabel yang menentukan efektif-tidaknya kepemimpinan, yaitu: (1) hubungan antara pemimpin dengan yang dipimpin, (2) derajat struktur tugas, dan (3) kedudukan kekuasaan pimpinan. Jadi, kepemimpinan yang berhasil perlu membaca situasi dan kondisi serta menyesuaikan gaya kepemimpinannya. Keberhasilan kepemimpinan sangat dipengaruhi oleh: Human relationship pemimpin dengan yang dipimpin, Staffing dan organizing yang efektif dan profesional, dan Otoritas pemimpin yang kuat dan tegas.

5. Gaya atau Model Kepemimpinan Tiga Dimensi. William J. Reddin (1970) adalah pencetus gaya kepemimpinan tiga dimensi (three-dimensionalmodel). Dalam gaya ini, ada tiga kelompok yang saling berhubungan, yaitu gaya dasar, gaya efektif, dan gaya tak efektif. Tiga gaya itu diorientasi pada dua hal, yaitu orang (people oriented) dan tugas (task oriented). Orientasi orang ditentukan dalam staffing, yaitu menempatkan orang sesuai dengan keahliannya dan pengalaman kerjanya. Orientasi tugas adalah mempertimbangkan tugas-tugas yang 
mampu dilaksanakan oleh karyawan sesuai dengan keahlian dan pengalamannya ${ }^{7}$.

6. Gaya atau Model Kontinum. Vroom dan Yetton adalah pencetus gaya kontinum yang menyatakan bahwa kepemimpinan didasarkan pada dua macam kondisi utama, yaitu pemimpin bertindak sendiri ataumelibatkan anak buahnya dalam pengambilan keputusan. Dua macam kondisi tersebut ialah: (1) tingkat keefektifan teknis di antara para bawahan dan (2) tingkat motivasi serta dukungan para bawahan. Adakalanya pengambilan keputusan tidak melibatkan bawahannya karena menyangkut hal yang mendesak dan telah terukur oleh profesionalitas kepemimpinannya. Ada pula yang harus mengikut sertakan anak buahnya untuk memberikan gagasan-gagasannya dalam upaya pengembangan kemajuan organisasi. Berdasarkan kedua macam kondisi tersebut, seorang pemimpin dapat memilih salah satu dari empat gaya kepemimpinan yang akan diterapkan dalam hubungannya dengan pembuatan keputusan. a) Jika tingkat keefektifan teknis dan tingkat motivasi dukungan bawahan keduanya rendah, pemimpin memilih gaya membuat keputusan sendiri (make decision alone); b) Jika tingkat keefektifan teknis dari bawahan tinggi, tetapi tingkat motivasi dan dukungan bawahan rendah, gaya kepemimpinan yang dipilihnya adalah membuat putusan secara konsultatif (consult): pimpinan berkonsultasi dengan bawahan; c) Jika tingkat keefektifan teknis dari bawahan rendah, tetapi tingkat motivasi dan dukungan bawahan tinggi, gaya kepemimpinan yang sesuai adalah dengan mendelegasikan (delegate) atau melimpahkan kepada bawahan. Pemimpin membuat putusan, kemudian melimpahkan tanggung jawab kepada bawahan untuk melaksanakannya; d) Jika tingkat keefektifan teknis maupun tingkat motivasi dukungan bawahan keduanya tinggi, maka gaya kepemimpinan yang sesuai adalah membuat keputusan bersama (share decision). Pemimpin bersama bawahan membuat putusan secara bermusyawarah.

7. Gaya Kepemimpinan Laissez Faire. Gaya ini seolah-olah tidak mengenal hierarki struktural, tidak ada atasan dan bawahan, pembagian tugas yang kabur, dan tidak terjadi proses kepemimpinan fungsional mupun struktural.

8. Kepemimpinan yang Demokratis. Gaya kepemimpina demokratis disebut juga dengan gaya kepemimpinan modernis dan partisipasif.

7 Miftah Thoha. Kepemimpinan dalam Managemen. (Jakarta: PT. Raja Grafindo Persada, 2015), hlm. 167-168

$196 \mid$ JURNAL LISAN AL-HAL 
Dalam pelaksanaan kepemimpinan, semua anggota diajak berpartisipasi menyumbangkan pikiran dan tenaganya untuk mencapai tujuan organisasi. Gaya demokratis adalah kebalikan dari gaya otokratis. Pemimpin yang bertipe demokratis adalah yang memiliki ciriciri sebagai berikut: a) Pengembangan sumber daya dan kreativitas karyawan; b) Pengembangan partisipatif karyawan; c) Musyawarah dan mufakat; d) Kaderisasi yang sistematis; e) Pendelegasian normatif yang konstruktif; dan f) Regenerasi kepemimpinan.

9. Gaya Kepemimpinan Kharismatik. Kharisma dapat dibagi dua macam, yaitu: a) Kewibawaan alamiah, yaitu kewibawaan yang telah ada pada diri pemimpin dan b) Kewibawaan buatan, yaitu kewibawaan yang diciptakan oleh jabatan dan kekuasaan.

\section{F. Teori Teori Kepemimpinan}

Teori-teori kepemimpinan adalah sebagai berikut ${ }^{8}$ : Pertama, Teori genetic, yaituseorang yang menjadi pemimpin karena sudah dilahirkan untuk menjadi pemimpin. Kepemimpinan merupakan pembawaan yang ditetapkan oleh Tuhan secara deterministic. Di samping itu, kepemimpinan diturunkan dari orang tuanya yang juga sebagai seorang pemimpin. Misalnya, mantan Presiden Soekarno adalah pemimpin yang jiwa kepemimpinannya diturunkan kepada Megawati Soekarno Putri. Kedua, Teori sosial, yaitu berpandangan bahwa pemimpin dilahirkan oleh kelompok tertentu. Keberhasilan kepemimpinannya sangat ditentukan oleh dukungan kelompoknya. Jika kelompoknya lari dari lingkungan organisasi yang dipimpinnya, secara otomatis sang pemimpin pun tamat riwayatnya.

Ketiga, Teori situasional, yang berpandangan bahwa lahirnya pemimpin bergantung pada situasi dan kondisi. Pelaksanaan kepemimpinan harus disesuaikan dengan situasi dan kondisi. Seperti pemimpin negara yang diciptakan oleh konstitusi dan keterlibatan rakyat secara langsung yang memilihnya. Sementara para pemimpin negara akan menerapkan gaya kepemimpinannya dengan mempertimbangkan situasi dan kondisi. Keempat, Teori ekologis, teori yang berpandangan bahwa lingkungan sangat memengaruhi kepemimpinan. Seluruh aspek yang berhubungan dengan lingkungan, misalnya pendidikan dan pelatihan, bakat, situasi dan kondisi, memengaruhi gaya kepemimpinan.

Tiga teori di atas dikembangkan oleh beberapa tokoh dalam teori-

8 Yusak Burhanuddin. Administrasi Pendidikan. (Bandung: Pustaka Setia. 2004), hlm 125-130. 
teori kepemimpinan yang lebih luas. Misalnya James Owens dalam The Leadership Game menyebutkan tiga teori kepemimpinan, yaitu: Trait theory, Behavior theory dan Matrix of leadership style.

Ketiga teori kepemimpinan yang dikemukakan oleh James Owens adalah teori sifat, teori perilaku, dan teori situasional. Oleh karena itu, sebenarnya tidak ada pengembangan yang berarti. Robert Tannenbaum dan Fred Massarik dalam Leadershipnya A Frame of Reference memperkenalkan beberapa teori atau pendekatan kepemimpinan, yaitu: Trait approach, Situasional approach, Follower-oriented approach, Environment theory, Personal-situasional theory, Interction-expectation theory, Humanistic theory, dan Exchange theory.

Trait theory sering disebut juga teori genetis atau teori bakat karena ia menganggap bahwa pemimpin itu dilahirkan bukan dibentuk. Behavior theory berpandangan bahwa kepemimpinan diciptakan oleh hubungan antar manusia. Oleh karena itu, keberhasilan seorang pemimpin sangat ditentukan oleh kemampuan pemimpin itu sendiri dengan anggotanya. Humanistic theory adalah teori yang berpandangan tentang gaya kepemimpinan manusiawi yang digambarkan oleh Huseman melalui lima gaya kepemimpinan, yaitu: (1) gaya otokratis, (2) gaya birokratis, (3) gaya diplomatis, (4) gaya partisipatis, dan (5) gaya free rein leader.

Environment theory (teori lingkungan) perna dikembangkan oleh V.H Vroom dan Philip Yellow (1973) dengan mengacu pada pendekatan situasional yang berusaha meberikan model normatif. Mereka berasumsi bahwa kepemimpinan akan berhasil apabila pemimpin mampu bersikap fleksibel untuk mengubah gayanya agar cocok dengan situasi dan kondisi ${ }^{9}$. Exchange theory atau teori pertukaran yang merupakan modifikasi dari teori sifat dan teori perilaku. Kepemimpinan menurut teori ini dibentuk dan dikembangkan oleh adanya pertukaran sosial, saling bergantiannya posisi dan jabatan, naik-turunnya kedudukan pejabat akan membangun situasi kepemimpinan yang sinergis.

Personal situasional theory atau teori pribadi dan situasi menyatakan bahwa kepemimpinan merupakan produk terpadunya tiga faktor, yaitu: (1) perangai (sifat-sifat) pribadi dari pemimpin, (2) sifat dari kelompok dan angota-anggotanya, (3) kejadian-kejadian (masalahmasalah) yang dihadapi oleh kelompok. Interaction-expectation theory atau teori interaksi dan harapan merupakan perpaduan antara teori perilaku dan lingkungan. Teori ini pada prinsipnya sama dengan 170.

9 Ngalim Purwanto. Administrasi Pendidikan. (Jakarta: Mutiara, 1984), hlm. 167-

198 JURNAL LISAN AL-HAL 
kontingensi (contingency theory) dari F.E. Fileder (1967) dan expectancyreinforcement theory dari Stogdill (1959). M.G. Evans (1970) mengistilahkan teori ini dengan path-goal theory, yang dikembangkan oleh Robett J. House dan Terence R. Mitchell (1979) dengan nama motivasional theory.

Teori motivasi mengembangkan gaya kepemimpinan melalui pembentukan hubungan komunikatif dan interaksi para anggota organisasi. Semakin tinggi tingkat komunikasi atau semakin dekatnya hubungan antar anggota, atasan dengan bawahan, semakin banyak menciptakan dalam organisasi. Interaksi antar anggota, pemimpin dan bawahan menambah pengetahuan dan pertukaran pengalaman yang signifikan, sehingga proses pergantian pemimpin serta pola dan gaya kepemimpinan akan semakin dinamis.

\section{G. Pemimpin Ideal Bagi Lembaga Pendidikan}

Pemimpin lembaga pendidikan adalah pemimpin yang di ciptakan oleh hal-hal sebagai berikut: 1) Peraturan perundang-undangan yang berlaku, anggaran dasar dan anggaran rumah tangga, status perguruan tinggi, dan norma-norma lainnya yang disepakati oleh anggota suatu lembaga pendidikan, karena lembaga pendidikan yang berbentuk yayasan biasanya dikuasai oleh dewan pendiri sekaligus mungkin pemilik yayasan; 2) Aturan main memilih pemimpin, seperti memilih pemimpin perguruan tinggi oleh anggota sanat, misalnya rektor atau dekan; 3) Pemimpin lembaga ditetapkan oleh penguasa berdasarkan jenjang karier, misalnya kepala sekolah menjadi penilik, wakil kepala sekolah diangkat menjadi kepala sekolah; dan 4) Pemimpin yang bersifat turun-temurun, misalnya pemimpin pondok pesantren tradisional yang kepemimpinannya bersifat genetik dan bergaya monarki absolut, sehingga kepemimpinan diwariskan kepada anak-anaknya ${ }^{10}$.

Pemimpin yang ideal untuk lembaga pendidikan adalah yang memiliki sifat-sifat sebagai berikut. 1) Capacity, meliputi: Kecerdasan, Kewaspadaan, Kemampuan bicara, Keterampilan, dan Kemampuan nilai; 2) Achievment, meliputi: Gelar kesajarnaan, Pengetahuan, Keberhasilan, dan Kesehatan jasmani; 3) Responsibility, meliputi: Mandiri dan berinisiatif, Tekun, Agresif, Percaya diri, dan Futuristik; 4) Participation, meliputi: Aktif, Relationship, Pandai membangun team works, dan Adaptif; 5) Status, meliputi: Kedudukan sosial ekonomi, dan Popularitas; 6) hlm 97.

10 Yusak Burhanuddin. Administrasi Pendidikan. (Bandung: Pustaka Setia. 2004), 
Situation, meliputi: Mental yang baik, Status, Skill, Energik, Fleksibel, dan Goal oriented,

Mempertimbangkan idealisme yang ingin diraih oleh lembaga pendidikan, sebaiknya mengacu kepada sifat Nabi Muhammad SAW. Yang dapat dijadikan barometer oleh semua lembaga pendidikan. Sifat-sifatnya adalah sebagai berikut ${ }^{11}$ : Shidik, artinya jujur, Amanah, artinya terpercaya, Tablig, artinya komunikatif dan Fathanah, artinya cerdas.

Kepemimpinan Nabi Isa a.s., yang didambakan oleh umat manusia, yaitu pemimpin umat yang penuh dengan cinta dan kasih sayang kepada umatnya. Berkorban untuk kehidupan yang layak dan memiliki harga diri yang tinggi. Pemimpin yang ideal bagi lembaga pendidikan adalah pemimpin yang penuh kaish sayang dan bijaksana.

Idealitas kepemimpinan Nabi Musa a.s., patut dikembangkan dan dicontoh, karena Nabi Musa adalah nabi yang berani, tegas, dan tanpa pandang bulu dalam menghakimi orang yang salah. Ia telah melumpuhkan fir'aun dan berani menghadapi semua penyihir yang zalim. Pemimpin yang ideal untuk lembaga pendidikan adalah pemimpin yang tegas dan tidak mengembangkan nepotisme, kolusi, dan korupsi sehingga akan menciptakan lembaga pendidikan yang maju dan berkarakteristik akademik yang khas dan jelas.

Apabila kepemimpinan Nabi Isa dan Nabi Musa disintesiskan, sebagaimana antara gaya kepemimpinannya yang terlalu kasih dan sayang tetapi kurang tegas, atau kepemimpinan yang tegas, tetapi kurang lembut, lahirlah kepemimpinan gaya Rasullah SAW., yaitu Muhammad SAW., yang menjadi rahmat bagi semua alam, tetapi tegas terhadap orang-orang yang kufur.

Dalam konteks perguruan tinggi, pemimpin yang didambakan adalah pemimpin yang memiliki wawasan keilmuan tinggi. Minimal, ia adalah guru besar. Keterampilan lainnya yang perlu dikuasai adalah sebagai berikut ${ }^{12}$ : a) Penguasaan bahasa asing yang aktif, misalnya bahasa inggris dan bahasa arab; b) Memiliki relasi yang luas dengan lembaga pendidikan lainnya, di dalam dan di luar negeri; c) Memiliki relasi keahlian dan keilmuan yang mumpuni; d) Konseptor yang andal; e) Dipilih oleh wakil-wakil dosen (anggota senat) secara demokratis; f) Memiliki visi dan misi yang mengedepan dan mudah dimanifestasikan dalam kegiatan akademi dan manajerial lembaga; g) Bijaksana, jujur, berwibawa, dan

11 Asep Djihat Suyanto. Menjadi Guru Profesional. (Jakarta: Erlangga Group. 2013) hlm, 70

12 Ibid, hlm 110-116.

$200 \mid$ JURNAL LISAN AL-HAL 
amanah; h) Pandai menempatkan para karyawan sesuai dengan kapasitas dan profesionalitasnya; dan i) Tidak bergantung pada politik praktis, dan sebagainya.

Keterampilan pemimpin lembaga pendidikan harus ditunjang oleh kecerdasannya dalam memecahkanya masalah yang dihadapi oleh lembaga. Permasalahan yang dihadapi oleh lembaga pendidikan merupakan bagian dari dinamika kepemimpinan. Suatu permasalahan yang muncul dapat diukur dari segi jelas kedudukannya dalam struktur keilmuan yang dikembangkan oleh lembaga pendidikan.

Pemimpin yang tanggap terhadap permasalahan akan melakukan pengamatan terhadap latar belakang munculnya masalah dengan cara mengumpulkan informasi atau data yang akurat dan menyeleksi penyebab-penyebab permasalahan dan menyelesaikan permasalahan seara ilmiah, rasional, dan mendatangkan kemaslahatan ${ }^{13}$.

\section{H. Pengawasan dan Evaluasi Pendidikan}

Sebagaimana diuraikan, perencanaan tidak dapat dilepaskan dari unsur pelaksanaan dan pengawasan, termasuk pemantauan, evaluasi, dan pelaporan. Jika dalam perencanaan diperlukan pengawasan dan evaluasi agar tidak terjadi penyimpangan-penyimpangan, maka dalam pelaksanaan program juga dilakukan pengawasan dan evaluasi agar kinerja program dan hasilnya sesuian dengan perencanaan. Pengawasan dapat dilakukan secara prevektif dan represif. Pengawasan prevektif merupakan pengawasan yang merekat dengan perencanaannya, sedangkan pengawasan represif merupakan pengawasan fungsional atas pelaksanaan rencana, baik yang dilakukan secara internal maupun secara eksternal oleh aparat pengawasan yang ditugasi.

Pengawasan, menurut LAN-RI (2003) ialah suatu kegiatan untuk memperoleh kepastian apakah pelaksanaan pekerjaan atau kegiatan pendidikan telah dilakukan sesuai dengan rencana semula. Kegiatan pengawasan pada dasarnya membandingkan kondisi yang ada dengan yang seharusnya terjadi. Kehadiran pengawas di lingkungan organisasi pendidikan (madrasah) dan pemerintahan mula-mula diletakkan pada pengaduditan (auditing) berdasarkan aturan. Alat yang digunakan adalah audit dan orangnya disebut auditor (pemeriksa). Auditing adalah suatu proses sistematis untuk memperoleh dan mengevaluasi bukti secara objektif tentang kegiatan yang dilakukan. Hal ini diperlukan untuk menentukan tingkat kesesuaian antara kegiatan dengan kriteria yang telah

${ }^{13}$ Hikmat. Manajemen Pendidikan, (Bandung: Pustaka Setia, 2009), hlm. 54-55. 
ditetapkan serta mengkomunikasikan hasilnya kepada pihak-pihak terkait. Pada konteks tersebut, pengawasan memokuskan kegiatannya pada pengujian ketaatan pada ketentuan yang berlaku. Auditor akan mengandalkan metode audit ketaatan (compliance audit) untuk mendapatkan temuan apakah manajemen telah bertindak benar atau salah, sesuai atau menyimpang, akurat atau keliru. Orientasi audit pada masa lampau dengan perhatian utama pada terjadi tidaknya penyimpangan. Oleh sebab itu, diagnosis dan terapi yang diajukannya pun jangka pendek. Auditor yang berperan demikian disebut "anjing penjaga" (wathdog).

Pada perkembangan selanjutnya, peran pengawas meningkat sebagai tenaga ahli (expert) atau konsultan. Pengawasan internal organisasi pendidikan (madrasah) khususnya berperan sebagai konsultan. Pengawasan mulai berorientasi pada identifikasi kelemahan-kelemahan operasional dan manajerial. Pengawasan dalam konteks ini lebih mengandalkan auditing operasional sebagai alat audit utama. Dengan mengadakan identifikasi berbagai alternatif pola operasional atau metode manajemen, auditor melahirkan sejumlah saran perbaikan yang dapat dilaksanakan. Jadi, pola pikir pengawas sebagai wathdog telah berubah ke posisi konsultan yang mendorong pengawasan untuk memberikan nilai tambahnya secara optimal. Pada level yang lebih ideal, pengawasan harus mampu memastikan bahwa saran-sarannya dapat dilaksanakan dengan baik. Dalam hal ini auditor harus mampu berperan sebagai katalisator dan penjamin kualitas (quality assurer).

Kehadiran pengawas di madrasah akan bermakna apabila perannya dapat mencapai tujuan pengawasan, yakni 1) pihak yang diawasi (madrasah) merasa terbantu sehingga dapat mencapai tujuan dan misi secara efektif dan efisien, 2) menciptakan iklim keterbukaan, kejujuran, partisipasi, dan akuntabilitas, 3) menimbulkan iklim saling percaya di dalam dan di luar lingkungan operasi madrasah, 4) meningkatkan akuntabilitas madrasah, 5) meningkatkan kelancaran operasi madrasah, 6) mendorong terwujudnya pelaksaan pendidikan madrasah secara bersih dan berwibawa.

Pada lingkuan madrasah yang diselenggarakan oleh pemerintah maupun yang mendapat subsidi dari pemerintah, dikenal berbagai macam bentuk pengawasan. Beberapa di antaranya diuraikan singkat berikut ini. ${ }^{14}$

14 Syukur dan Ahmad. Manajemen Pendidikan Islam. (Yogyakarta: LaksBang Press Indo, 2011) hlm. 91.

202 JURNAL LISAN AL-HAL 
Pertama, Pengawasan Melekat. Istilah pengawasan melekat (waskat) pertama kali muncul dalam Inpres No. 15 Tahun 1983 tentang Pedoman Pengawasan Melekat, yang menyebutkan bahwa yang dimaksud dengan pengawasan melekat ialah serangkaian kegiatan yang bersifat sebagai pengendalian yang terus-menerus, dilakukan langsung terhadap bawahannya, secara preventif dan refresif agar pelaksanaan tugas bawahan tersebut berjalan secara efektif dan efesien sesuai dengan rencana kegiatan dan peraturan perundang-undangan yang berlaku. Pada pengawasan melekat, pelaku pengawasan adalah atasan yang dianggap memiliki kekuasaan (power) dan dapat bertindak bebas dari konflik kepentingan. Dalam konsep pengawasan melekat, para pelaku pengawasan lainnya seperti bawahan, orang lain, sistem, dan masyarakar kurang diperhatikan dengan anggapan atasan dapat menjalankan kekuasaannya sehingga bebas mengawasi bawahannya.

Kedua, Pengawasan Fungsional. Istilah pengawasan fungsional secara resmi pertama kali muncul dalam Inpres No. 15 Tahun 1983 tentang Pedoman Pelaksanaan Pengawasan, yang menyebutkan bahwa pengawasan fungsional ialah setiap upaya pengawasan yang dilakukan oleh aparat yang ditunjuk khusus untuk melakukan audit secara bebas terhadap objek yang diawasinya. Aparat pengawas fungsional melakukan tugas berupa pemeriksaan, verifikasi, konfirmasi, survei, penilaian (evaluasi), audit, dan pemantauan (monitoring). Verifikasi ialah mencocokkan jumlah dan kualitas barang atau jasa dengan bukti-buktinya, misalnya kuitansi. Sedangkan investigasi ialah menemukan penyimpangan mengapa kualitas, jumlah, dan harganya tidak wajar.

Ketiga, Pengawasan Internal dan Eksternal. Sebagaimana tercermin dalam manajemen pada umumnya, dalam manajemen pendidikan islam juga dikenal dua jenis strategi pengawasan, yakni pengawasan internal dan pengawasan eksternal. Strategi pengawasan internal mengandaikan pemberian kepercayaan (trust) kepada orang untuk mengendalikan perilaku mereka sendiri dalam melaksanakan operasi madrasah. Strategi ini membiarkan individu dan kelompok yang termotivasi untuk melakukan disiplin diri untuk memenuhi harapan pekerjaan pendidikan. Alternatif strategi yang lain, kepala sekolah selaku manajer dapat melakukan tindakan langsung untuk mengendalikan perilaku-perilaku orang lain. Strategi tersebut adalah strategi pengawasan eksternal, yang terjadi melalui supervisi pendidikan atau pengajaran dan menggunakan sistem administrasi formal. Tipe pengawasan yang efektif melibatkan kombinasi dari kedua strategi tersebut, yaitu disamping menggunakan strategi internal, juga menggunakan strategi eksternal. Namun untuk 
madrasah yang baru, cara pengawasannya adalah dengan menitikberatkan pada partisipasi, pemberdayaan, dan pelibat, yang menempatkan kepercayaan yang lebih tinggi pada pengawasan internal.

Strategi pengawasan internal memerlukan suatu tingkat kepercayaan yang tinggi. Ketika orang diharapkan untuk bekerja pada kemauannya sendiri dan melakukan pengendalian diri, kepala madrasah selaku manajer harus memberikan kebebasan pada pendidik, tenaga kependidikan dan karyawan madrasah untuk berbuat. Menurut perspektif Teori Y Douglas McGregror (1961), orang bersedia dan mau untuk melakukan pengendalian diri dalam pekerjaannya. Tetapi ia juga menekankan bahwa pendidik, tenaga kependidikan dan karyawan akan melakukan seperti itu jika mereka diberi kesempatan untuk berpartisipasi dalam menentukan tujuan, sasaran, dan standar kinerja. Jika prosesnya berjalan lancar, potensi pengendalian diri meningkat ketika orang mempunyai kemampuan memahami misi madrasah yang tertuang dalam tujuan madrasah dan mempunyai kemampuan untuk melakukan pekerjaan pendidikan dengan baik. Potensi pengendalian diri dapat ditingkatkan dengan budaya pendidikan yang partisipatif yang setiap orang memerlukan orang lain dengan hormat menghormati. Perlu diketahui banyak pekerjaan pendidikan dewasa ini sangat memerlukan pengawasan internal.

Pada lingkuan madrasah, manfaat pengawasan internal antara lain: 1) Menjembatani hubungan pimpinan tertinggi (kepala madrasah) dengan para manajer lain (wakil kepala madrasah) dan staf dalam rangka memperkecil ketimpangan informasi; 2) Mendapatkan informasi keuangan pendidikan dan penggunaan yang dapat dan dapat dipercaya; 3) Menghindari atau mengurangi risiko pendidikan; 4) Memenuhi standar yang memuaskan; 5) Mengetahui penerimaan atau ketaatan terhadap kebijakan dan prosedur internal; 6) Mengetahui efisiensi penggunaan sumber daya pendidikan atau kepastian terwujudnya penghematan; dan 7)Efektivitas pencapaian tujuan pendidikan. Manfaat pengawasan eksternal adalah untuk meningkatkan kredibilitas keberhasilan dan kemajuan madrasah. Pelaksanaan pengawasan eksternal dilakukan dengan prinsip kemitraan (partnership) antara pengawas dengan tim madrasah ${ }^{15}$.

15 Muljasa. Managemen Pendidikan Karakter. (Yogyakarta: Bumi Aksara, 2012), hlm. 189-190.

204 JURNAL LISAN AL-HAL 


\section{Program Pengawasan}

Madrasah menyusun program pengawasan secara objektif, bertanggungjawab dan berkelanjutan. Penyusuna program pengawasan di madrasah didasarkan pada Standar Nasional Pendidikan. Program pengawasan disosialisasikan ke seluruh pendidik dan tenaga kependidikan. Pengawasan pengelolaan madrasah meliputih pemantauan, supervsi, evaluasi, pelaporan, dan tindak lanjut hasil pengawasan. Pemantauan pengelolaan madrasah dilakukan oleh komite madrasah atau bentuk lain dan lembaga perwakilan pihak-pihak yang berkepentingan secara teratur dan berkelanjutan untuk menilai efisiensi, efektivitas, dan akuntabilitas pengelolaan. Supervisi pengelolaan akademik dilakukan secara teratur dan berkelanjutan oleh kepala madrasah dan pengawas madrasah $^{16}$.

Guru melaporkan akhir semester yang ditujukan kepada kepala amadrasah dan orang tua/wali peserta didik. Tenaga kependidikan melaporkan pelaksanaan teknis dan tugas masing-masing sekurangkurangnya setiap akhir semester yang ditujukan kepada kepala madrasah. Kepala madrasah secara terus menerus melakukan pengawasan pelaksanaan tugas tenaga kependidikan. Kepala madrasah melaporkan hasil evaluasi kepada komite madrasah dan pihak-pihak lain yang berkepentingan sekurang-kurangnya setiap akhir semester. Pengawas madrasah melaporkan hasil pengawasan di madrasah kepada Kantor Departemen Agama Kabupaten/Kota dan pada madrasah yang bersangkutan, setelah dikonfirmasikan pada madrasah terkait ${ }^{17}$.

Setiap pihak yang menerima laporan hasil pengawasan menindaklanjuti laporan hasil pengawasan tersebut dalam rangka meningkatkan mutu madrasah, termasuk memberikan sanksi atas penyimpangan yang ditemukan. Madrasah mendokumentasikan dan menggunakan hasil pemantauan, supervisi, evaluasi, dan pelaporan serta catatan tindak lanjut untuk memperbaiki kinerja madrasah dalam pengelolaan pembelajaran dan pengelolaan secara keseluruhan.

\section{J. Evaluasi Diri}

Madrasah melakukan evaluasi diri terhadap kinerja madrasah. Madrasah menetapkan prioritas indikator untuk mengukur,menilai kinerja, dan melakukan perbaikan dalam rangka pelaksanaan Standar hlm, 102.

${ }^{16}$ Asep Djihat Suyanto. Menjadi Guru Profesional. (Jakarta: Erlangga Group. 2013)

17 Ibid, hlm. 60. 
Nasional Pendidikan. Evaluasi diri madrasah dilakukan secara periodik berdasar pada data dan informasi yang sahih. Pada konteks tersebut, Madrasah melaksanakan: 1) Evaluasi proses pembelajaran secara periodik, sekurang-kurangnya dua kali dalam setahun, pada akhir semester akademik dan 2) Evaluasi program kerja tahunan secara periodik sekurang-kurangnya satu kali dalam setahun, pada akhir tahun anggaran madrasah.

Ada dua hal penting yang mesti dipahami oleh kepala madrasah dan unit kerjanya dalam evaluasi diri, terutama untuk evaluasi program kerja tahunan, yaitu apa yang dimaksud dengan kinerja dan bagaimana menentukan kriteria, standar, dan indikatornya.

Konsep kinerja merupakan suatu istilah dalam manajemen yang didefinisikan melalui perspektif atau sudut pandang yang berbeda oleh para ahli. Konseptualisasi tersebut sangat tergabtung dari implementasi di instituisi apa pengertian tersebut ditempatkan. Konsep kinerja merupakan akronim dari kinetika energi kerja yang padanannya dalam bahasa inggris adalah performar. Juga berarti prestasi kerja, pelaksanaan kerja, pencapaian kerja, hasil kerja, unjuk kerja, atau penampilan kerja.

Menurut Gibson, Ivancevich dan Donnelly, dikatakan bahwa kinerja adalah tingkat keberhasilan dalam melaksanakan tugas dan kemampuan untuk mencapai tujuan yang ditetapkan. Batasan tersebut mengandung makna bahwa kinerja dinyatakan baik dan sukses, jika tujuan yang diinginkan dapat tercapai dengan baik. Hal yang sama dinyatakan Rivai dan Basri, bahwa kinerja adalah hasil atau tingkat keberhasilan seseorang secara keseluruhan selama periode tertentu dalam melaksanakan tugas dibandingkan dengan berbagai kemungkinan, seperti standar hasil kerja, target atau sasaran atau kriteria yang telah ditentukan terlebih dahulu telah disepakati bersama. Kinerja juga merupakan alat ukur manajemen yang digunakan untuk menilai tingkat pertanggungjawaban seseorang dalam melakukan tugasnya ${ }^{18}$.

Kinerja adalah keluaran yang dihasilkan oleh fungsi-fungsi atau indikator-indikator suatu pekerjaan atau profesi dalam waktu tertentu. Kinerja merupakan gambaran mengenai tingkat pencapaian pelaksanaan suatu kegiatan/program/kebijakan organisasi dalam mewujudkan organisasi, outcome hasil kerja organisasi dalam mewujudkan tujuan strategis yang ditetapkan organisasi, kepuasan pelanggan, serta kontribusinya terhadap perkembangan ekonomi masyarakat. Kinerja juga

18 Max Weber. The Sosiology of Religion, Sosiologi Agama. Penerjemah Muhammad Yamin. (Yogyakarta: IRCiSoD. 2002), hlm. 203-205.

206 JURNAL LISAN AL-HAL 
dapat dikatakan sebagai perilaku berkarya, penampilan, atau hasil karya. Oleh karena itu, kinerja merupakan bentuk bangunan yang multidimensional sehingga cara mengukurnya sangat bervariasi tergantung pada banyak faktor ${ }^{19}$..

Suatu pekerjaan atau profesi mempunyai sejumlah indikator yang dapat digunakan untuk mengukur hasil pekerjaan tersebut. pada Bab III sudah diuraikan tentang bagaimana menentukan indikator kinerja, mulai dari indikator masukan, keluaran, hasil, manfaat dan indikator dampak. Pada bagian ini ditambahkan mengenai kriteria kinerja karena setiap evaluasi mempersyaratkan kriteria. Setiap indikator kinerja diukur berdasarkan kriteria standar tertentu. Dalam mengukur kinerja, terdapat kriteria atau ukiran. Kriteria tersebut antara lain berikut ini.

Pertama, Kuantitatif (seberapa banyak). Ukuran kuantitatif merupakan ukuran paling mudah untuk disusun dan mengukurnya, yaitu hanya dengan menghitung seberapa banyak unit keluaran kinerja harus dicapai dalam kurun waktu tertentu. Contoh: a) Guru A menghasilkan tidak kurang dari sepuluh silabus pembelajaran selama dua semester; b) Guru B melakukan dan menyelesaikan satu survei selama setahun; c) Guru C minimal menulis dua naskah jurnal yang dipublikasikan pada jurnal ilmiah nonakreditasi; d) Guru D menyelenggarakan tes blok atau ulangan harian sebanyak lima kali dalam satu semester; e) Guru E melayani konseling minimal 15 siswa dalam seminggu; dan f) Guru F mengenalkan minimal dua metode pembelajaran baru dalam satu tahun.

Kedua, Kualitatif (seberapa baik). Melukiskan seberapa baik atau seberapa lengkap hasil harus dicapai. Kriteria ini antara lain mengemukakan akurasi, presisi, penampilan (kecantikan dan ketampanan), kemanfaatan atau efektivitas. Standar kualitas dapat diekspresikan sebagai tingkat kesalahan seperti jumlah atau persentase kesalahan yang diperbolehkan per unit hasil kerja. Contoh: a) Laporan evaluasi yang diajukan guru diterima tanpa revisi minimal 75\%; b) Modul mata pelajaran dihasilkan sesuai dengan standar kualitas ilmiah penulisan minimal 95\%; c) Tingkat keberhasilan konseling terhadap para peserta didik yang bermasalah tidak kurang dari 80\%; dan d) Keluhan orang tua peserta didik terhadap layanan pembelajaran anak-anaknya maksimal hanya $1 \%$ per semester.

Ketiga, Ketepatan waktu pelaksanaan tugas atau penyelesaian pekerjaan. Kriteria yang menentukan keterbatasan waktu untuk melakukan pekerjaan atau layakan pembelajaran. Kriteria ini menjawab

${ }^{19}$ Tim Departemen Keuangan RI \& Kemenegrembang/Bappenas, 2009. 
pertanyaan, seperti kapan, berapa cepat, atau dalam periode apa. Contoh: a) Mikroskop telah berada di ruang laboratonium IPA dalam waktu 10 menit setelah dipesan untuk praktikum (timely services PLP); b) Hasil ulangan harian disampaikan kepada para peserta didik dalam waktu $1 \mathrm{x}$ 24 jam; c) Permohonan penerimaan gaji guru dan pegawai diajukan sebelum tanggal 15 setiap bulannya dan d) Laporan pertanggungjawaban keungangan setiap tahun selesai maksimal dua minggu sebelum tutup buku (tanggal 15 Desember).

Keempat, Efektivitas penggunaan sumber madrasah. Efektivitas penggunaan sumber dijadikan indikator jika untuk mengerjakan suatu pekerjaan disyaratkan menggunakan jumlah sumber tertentu, seperti uang dan bahan baku. Contoh: a) Biaya perjalanan tidak melebihi 5\% biaya perjalanan tahun yang lalu; b) Melakukan penghematan pemakaian listrik sampai $10 \%$ dari tahun yang lalu; c) Anggaran BBM untuk kendaraan dinas turun 25\% dari anggran tahun lalu; dan d) Bahan baku laboratorium yang terbangun dalam proses pembelajaran tidak melebihi 0,002\%.

Kelima, Cara melakukan pekerjaan, digunakan sebagai standar kinerja jika kontak personal, sikap personal, atau perilaku karyawan merupakan faktor penentu keberhasilan melaksanakan pekerjaan. Contoh: a) Membantu penyelesaian masalah peserta didik dan menjelaskan solusinya dengan benar; b) Memilih perkataan yang sopan ketika memberikan teguran kepada peserta didik dalam proses pendidikan dan pembelajaran; c) Berperilaku sopan dan saling menghormati terhadap sesama rekan guru, atasan, maupun, para pihak yang berkepingan; d) Membantu teman sekerja yang memerlukan bantuan dengan sabar walaupun sibuk mengerjakan pekerjaannya sendiri; dan e) Mematuhi peraturan, tata tertib, dan kode etik madrasah.

Keenam, Efek atas suatu upaya. Pengukuran yang diekspresikan akibat akhir yang diharapkan akan diperolah dengan bekerja. Standar jenis ini menggunakan kata-kata sehingga dan anggar supaya yang digunakan jika hasilnya tidak dapat dikualifikasikan. Contoh: a) Membeli bahan keperluan pembelajaran dengan menggunakan prinsip just in time supaya tersedia ketika diperlukan dan biaya penyimpanannya rendahdan b) Mematikan lampu dan air condition (AC), atau keran air ketika meninggalkan ruangan sehingga biaya pemakaian listrik dan air dapat dihemat.

Ketujuh, Metode melaksanakan tugas. Standar yang digunakan jika ada undang-undang, kebijakan, standar operasional prosedur (SOP), metode, dan peraturan untuk menyelesaikan tugas atau jika cara pengecualian ditentukan tidak dapat diterima. Contoh: a) Penilaian 
terhadap proposal survei yang didanai madrasah dilakukan berdasarkan standar penilaian karya ilmia dan diselesaikan dalam waktu maksimal 20 (dua puluh) hari kerja; dan b) Pemeriksaan terhadap guru yang diduga melanggar kode Etik Guru Indonesia (KEGI) hanya dapat dilakukan berdasarkan minimal dua orang saksi dan dilakukan di depan anggota Dewan Kehormatan Guru (DKG).

Kedelapan, Standar sejarah. Standar yang menyatakan hubungan antara standar masa lalu dengan standar sekarang. Standar masa sekarang dinyatakan lebih tinggi atau lebih rendah dari pada standar masa lalu dalam pengertian kuantitas dan kualitas. Contoh: a) Peserta didik yang tinggal kelas harus 50\% lebih rendah dibandingkan tahun pelajaran yang lalu; b) Rata-rata hasil ujian akhir nasional (UAN) peserta didik harus meningkat 3 (tiga) poin dibanding rerata hasil UAN pada tahun lalu; dan 3) Peserta didik yang tidak lulus harus 0 (nol) persen dibanding tahun lalu yang mencapai $1 \%$.

Kesembilan, Standar nol atau absolut. Standar yang menyatakan tidak akan terjadi sesuatu. Standar ini dipakai jika tidak ada alternatif lain. Contoh: a) Tidak ada pelecehan seksual terhadap peserta didik; b) Tidak terjadi kekerasan terhadap peserta didik dalam proses pendidikan dan pembelajaran; c) Tidak terjadi korupsi dalam pelaksanaan rencana anggaran dan belanja madrasah (RABM); dan d) Tidak terjadi plagiarisme (penjiplakan) dalam penulisan karya ilmiah yang dilakukan oleh guru.

\section{K. Simpulan}

Kepemimpinan kependidikan adalah sebagai satu kemampuan dan proses mempengaruhi, membimbing, mengkoordinir dan menggerakkan orang-orang lain yang ada hubungannya dengan perkembangan ilmu pendidikan dan pelaksanaan pendidikan dan pengajaran, agar supaya kegiatan-kegiatan yang dijalankan dapat lebih efektif dan efisien di dalam mencapai tujuan pendidikan dan pengajaran. Kepemimpinan mempunyai peran besar dalam mendinamisasi potensi sekolah. Kepemimpinan yang dinamis, progresif, dan responsif akan membuka suasana baru, segar, dan penuh kekeluargaaan. Masing-masing elemen merasa dihargai dan mempunyai tanggung jawab besar dalam melakukan pekerjaan sesuai bidangnya masing-masing.

Kepemimpinan pendidikan seyogyanya selalu mengikuti perkembangan pengetahuan teknologi, peradaban, pemikiran dan informasi globa juga terus berjalan secara kooperatif. Dengan begitu, sekolah dapat selalu aktual, relevan terhadap perubahan dan perkembangan tanpa kehilangan karakter aslinya. Ada beberapa unsur 
yang terlibat dalam situasi kepemimpinan yaitu: 1) Orang yang dapat mempengaruhi orang lain disatu pihak; 2) Orang yang dapat pengaruh dilain pihak; 3) Adanya maksud-maksud atau tujuan-tujuan tertentu yang hendak dicapai; dan 4) Adanya serangkaian tindakan tertentu untuk mempengaruhi dan untuk mencapai maksud atau tujuan tertentu. Apabila diambil sarinya, kepemimpinan pendidikan merupakan kemampuan untuk menggerakkan pelaksanaan pendidikan untuk mencapai tujuan pendidikan. Penegrtian ini sejalan dengan sudut filosofi kepemimpinan yang ada pokonya menjunjung tinggi asas hubungan kemanusian.

\section{DAFTAR PUSTAKA}

Anggara. Sistem Politik Indonesia. Bandung: Personal Press. 2009.

Athoilah, Anton. Dasar-dasar Manajemen. Bandung: Fak. Syari'ah IAII Sunan Gunung Djati. 2002.

Bahri Djamarah, Syaiful dan Zain, Aswa. Strategi Belajar Mengajar. Jakarta. PT. Rineka Cipta. 2002.

Bakri, Syaiful. Prestasi Belajar dan Kompetensi Guru. Jakarta. PT Rineka Cipta. 2002

Burhanuddin, Maisyarah \& Imran Ali. Managemen Pendidikan. Surabaya. UM Malang. 2003

Burhanuddin, Yusak. Administrasi Pendidikan. Bandung: Pustaka Setia. 2004.

Daryanto. Administrasi Pendidikan. Bandung: Pustaka Setia. 2005.

Husnan, Suad dan Pudjiastuti, Enny. Dasar-dasar Manajemen Keuangan. Yogyakarta: UPP. AMP YKPN. 2004.

Malayu S.P. Hasibun. Manajemen Sumber Daya Manusia. Jakarta: Bumi Aksara. 2005.

Muhammad, Muhyiddin. ESQ Power for Better Life. Yogyakarta. Tunas Publishing. 2006.

Muljasa. Managemen Pendidikan Karakter. Yogyakarta. Bumi Aksara. 2012. Purwanto, Ngalim. Administrasi Pendidikan. Jakarta. Mutiara. 1984.

Rachmawati, Ike Kusdyah. Manajemen konsep-konsep Dasar dan Pengantar Teori. Malang. UMM Press. 2003.

Soetarjo, Hendiat Dan Soemanto, Wasti. Kepemimpinan dan Supervisi Pendidikan. Bina Aksara.

Suyanto. Menjadi Guru Profesional. Jakarta. Erlangga Group. 2013.

Syah, Muhibbin. psikologi Pendidikan dengan Pendekatan Baru. Bandung. PT. Remaja Rosda Karya. 2007.

Thoha, Miftah. Kepemimpinan dalam Managemen. Jakarta. PT. Raja

$210 \mid$ JURNAL LISAN AL-HAL 
Grafindo Persada. 2015.

Turmuzi, Hamzah. Kepemimpinan Kyai (Penelitian Kyai Persis Garut), Tesis. Bandung: Unpad. 2002.

Weber, Max. The Sosiology of Religion, Sosiologi Agama. Penerjemah Muhammad Yamin. Yogyakarta: IRCiSoD. 2002.

Yusuf, Syamsul. Psikologi Perkembangan Anak dan Remaja. Cet. 1. Bandung: Rosda. 2000. 
"Kepemimpinan Pendidikan"

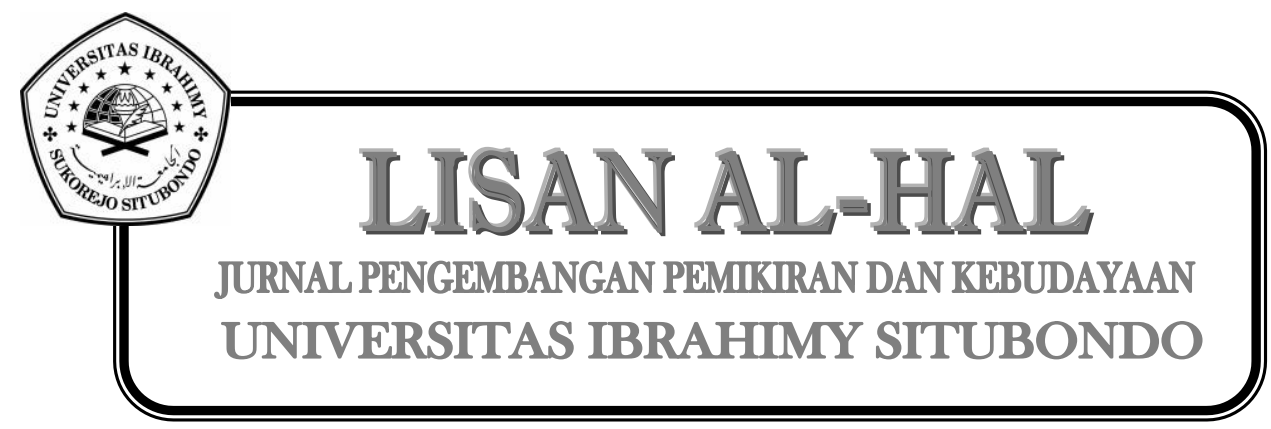

212 JURNAL LISAN AL-HAL 